\title{
AGROINDUSTRI BERBASIS TEH RAKYAT SEBAGAI USAHA MENINGKATKAN KESEJAHTERAAN PETANI TEH
}

\author{
Lucyana Trimo $^{1 *}$ dan Syarif Hidayat ${ }^{2}$ \\ 1. Prodi Agribisnis, Departemen Sosial Ekonomi Pertanian, Fakultas Pertanian, Universitas \\ Padjadjaran \\ 2. Prodi Agroteknologi, Departemen Hama dan Penyakit Tumbuhan, Fakultas Pertanian, \\ Universitas Padjadjaran \\ Email: lucy.trimo@gmail.com; lucyana.trimo@unpad.ac.id
}

\begin{abstract}
Abstrak
Penelitian dilakukan untuk mengkaji kendala yang dihadapi dan keberlanjutan agro-industri teh. Penelitian dilakukan dengan menggunakan pendekatan studi deskriptif survey. Tempat penelitian yang dipilih adalah Kabupaten: Garut (Kecamatan Cisurupan), Cianjur (Kecamatan Sukanagara) dan Bandung (Kecamatan Pasirjambu), yang merupakan sentra teh di Provinsi Jawa Barat.Data diperoleh melalui wawancara dengan:pejabat pada instansi pemerintah, koperasi, pabrikan, asosiasi petani teh, kelompok tani, serta petaniteh yang diambil secara purposive. Sedangkan responden diambil secara proposional dari ketiga wilayah penelitian, dansetiap kecamatan diambil 30 orang petani teh. Data dianalisis secara deskriptif, dengan pendekatan system thinking. Kendala yang dihadapi agroindustri teh rakyat, yaitu masih kurang dalam: 1) ketersediaan pucuk teh sebagai bahan baku, 2) pengetahuan untuk meningkatkan nilai tambah pucuk teh, 3) kemampuan penyediaan modal dan mesin olah pucuk teh, dan 4) dukungan pemerintah dalam mempromosikan teh olahan rakyat (misalnya: dalam rapat atau kegiatan yang berlangsung di pemerintahan belum memanfaatkan produk olahan teh dari petani). Kondisi ini berdampak terhadap keberlanjutan agroindustri teh rakyat.
\end{abstract}

Kata kunci: agroindustri, berkelanjutan, kemandirian, nilai tambah, teh rakyat.

\begin{abstract}
This research was conducted to investigate the constrain of tea small holder in agroindustry development.The study was conducted using a survey descriptive study approach. Selected location research is located at the center of tea small holder in West Java province, i.e.District of Garut, Cianjur and Bandung. In this research, the data were collected by interviews with relevant parties, i.e. officials at government agencies, cooperatives, manufacturers, associations of tea farmers, tea small holder groups, and tea farmers. While respondents were taken proportionally from the three study areas, and each district was taken by 30 tea farmers. Data were analyzed descriptively, with a system thinking approach. Constraints faced by the tea tea agro-industry, which are still lacking in: 1) the availability of tea shoots as raw materials, 2) knowledge to increase the added value of tea tops, 3) the ability to provide capital and tea shoot machines, and 4) government support in promoting tea processed by the people (for example: in meetings or activities that take place in the government have not utilized tea processing products from farmers). This condition has an impact on the sustainability of the people's tea agro-industry.
\end{abstract}

Key words : agro-industry, independence,sustainability,tea small holder, value added 


\section{Pendahuluan}

Dewasa ini ada kecenderungan bahwa pabrikan teh di negara-negara pengimpor teh Indonesia tidak lagi menjadikan teh Indonesia sebagai blending component, tetapi hanya sebagai filler saja. Oleh karena itu perbaikan mutu menjadi salah satu critical success factor dalam upaya Penyelamatan Agribisnis Teh Nasional (Dewan Teh Indonesia, 2012). Secara global teh sudah bukan merupakan bahan pangan yang diolah sebagai minuman saja, tetapi sudah menjadi bahan (produk antara) yang bisa ditambahkan pada produk aneka makanan, kosmetik dan biofarmaka. Salah satu contohnya adalah: tepung teh yang merupakan salah satu produk lanjutan teh yang bernilai tambah.Untuk memproduksi tepung teh tidak memerlukan teknologi yang cukup rumit dan teknologi tersebut telah tersedia di Indonesia sejak lama.. Pembuatan tepung teh dapat dilakukan secara sederhana melalui proses steaming, pengeringan, pengecilan ukuran partikel dan pengayakan hingga mencapai ukuran partikel tertentu sesuai dengan kebutuhan pasar. Selanjutnya, tepung teh tidak saja dapat diolah menjadi berbagai macam minuman, juga dapat diolah menjadi makanan berbasis tepung teh (coklat, dodol, kueh, dan lain-lain). Selain itu dapat menunjang berkembangnya biofarmaka.

Perkebunan teh rakyat, dapat maju berkembang dengan baik, jika orientasi paradigma pengelolaannya berkembang kearah agroindustri teh rakyat. Kelompok tani teh yang merupakan pelaku bisnis dalam usaha teh rakyat harus memiliki paradigma yang berorientasi bisnis. Artinya, mereka harus dapat bergerak dan berkembang kearah agroindustri. Melalui agroindustri mereka akan memperoleh nilai tambah dan memenuhi permintaan pasar yang semakin berkembang. Oleh karena itu, untuk membangun dan memberdayakan petani teh rakyat, harus dilakukan melalui perubahan paradigma kelompok tani kearah agroindustri. Hal ini karena, pasar nasional dan internasional terbuka lebar untuk teh olahan. Peluang untuk perubahan paradigma tersebut sangat tinggi karena pemerintah sudah mencanangkan Gerakan Penyelamatan Agribisnis Teh Nasional (GPATN).

Untuk menunjang perubahan paradigma kelompok tani, maka diperlukan penguatan dalam agroindustri teh rakyat, dan itu harus dimulai dari hulu (dalam penyediaan pucuk teh sebagai bahan baku dalam proses agroindustri teh) sampai ke hilir (inovasi dalam mengembangkan produk olahan teh dalam kegiatan agroindustri teh).Diharapkan, dengan melalui agroindustri teh, maka petani dan kelompok tani tidak lagi menjual produk hulu (pucuk teh), tetapi menjual produk antara (teh hijau) atau hilir (produk turunan dari teh hijau) yang memiliki nilai tambah lebih tinggi. Selanjutnya, dengan nilai tambah yang tinggi, akan berdampak kepada peningkatan pendapatan petani perkebunan teh rakyat, yang pada akhirnya dapat meningkatkan kesejahteraan mereka.

\section{Metode Penelitian}

Desain yang digunakan dalam penelitian ini adalah desain kualitatif. Penelitian kualitatif adalah suatu bentuk penelitian yang menghasilkan karya ilmiah dengan menggunakan data diskriptif yang berupa kata-kata tertulis atau lisan dari orang-orang atau perilaku yang dapat diamati terhadap status kelompok orang atau manusia suatu obyek atau suatu kelompok kebudayaan (Lexi J. Moleong, 2001). Sedangkan teknik penelitian yang digunakan dalam penelitian ini adalah studi kasus (case study). Menurut Suharsimi (2002), penelitian studi kasus adalah suatu penelitan yang di lakukan secara intensif, terinci dan mendalam terhadap suatu organisasi, lembaga atau gejala tertentu. Hal yang sama diungkapkan oleh Rusidi (2002), yang menyatakan bahwa 
Studi kasus adalah metode penelitian deskriptif yang objek peristiwanya adalah peristiwa sekarang, hanya satu unit kasus, dapat berupa kesatuan social tertentu, orang seorang, satu keluarga, satu kelompok atau organisasi dalam suatu masyarakat, satu komunitas tertentu, dan sebagainya yang merupakan penelitian yang bersifat eksploratif dan mendalam.

Teknik pengumpulan data dilakukan dengan cara: studi kepustakaan dan wawancara dengan pihak terkait, yaitu pejabat pada lembaga/instansi pemerintah, koperasi, pabrikan, dan asosiasi petani teh yang dipilih secara purposive, kelompok tani, serta petani teh yang diambil secara acak sederhana dari setiap Kecamatan yang dijadikan sampel. Dari setiap Kecamatan diambil sampel secara proposional (berdasarkan luas wilayah sentra teh), dan di masing-masing Kecamatan diambil 30 orang sampel petani teh.

Selain teknik FGD dan wawancara, dalam pengumpulan data primer juga dilakukan melalui teknik observasi (pengamatan). Teknik pengamatan perlu dilakukan untuk melihat bagaimana kondisi realita kebun teh rakyat dan juga hasil teh olahan yang ada di teh rakyat.

Penggalian data sekunder juga dilakukan untuk melengkapi data primer, yaitu dengan cara: mengumpulkan dan mempelajari data tertulis berupa dokumen-dokumen atau transkip, koran, jurnal, bulletin, dan membuka akses melalui internet mencari website yang terkait dengan penelitian ini. Data dan informasi yang diperoleh selanjutnya dianalisis secara deskriptifkorelatif dan menggunakan pendekatan system thinking. Alat yang digunakan dalam penelitian ini adalah melalui pendekatan system thinking, yaitu dengan causal loop modelling, dan salah satu alat yang dapat digunakan adalah Causal Loop Diagram (CLD) untuk mempermudah mendeskripsikannya.

\section{Hasil dan Pembahasan}

\section{TuntutanKonsumen Terhadap Makanan Berbasis Teh}

Berdasarkan hasil penelitian pada tahun 2015 (hasil kerjasama antara Unpad dengan BP3IPTEK) dapat diketahui bahwa konsumen di Jawa Barat lebih menyukai rasa dari makanan dan minuman kuliner serta oleh-oleh khas Jawa Barat yang memiliki rasa teh, sehingga hal ini merupakan pontensi untuk Jawa Barat sebagai sentra produsen teh di Indonesia untuk dapat mengembangkan industri makanan dan minuman khas Jawa Barat yang berbasis teh. Konsumen yang menyukai makanan dan minuman rasa teh mencapai $53 \%$, selebihnya yaitu $43 \%$ masih lebih menyukai rasa non teh dengan berbagai alasan, antara lain karena harga makanan dan minuman rasa teh harganya lebih mahal dan ukurannya lebih kecil serta teksturnya yang masih kurang lembut. Selanjutnya, untuk jenis kue khas Jawa Barat berbasis teh, ternyata kue cubit rasa green tea merupakan jenis kue yang paling favorit di Jabar (36\%), diikuti oleh brownish pada pilihan kedua (19\%). Lapis Bogor dan roti rasa green tea, masing-masing hanya menempati pilihan favorit sebesar $14 \%$ dari seluruh responden (Gambar 1).

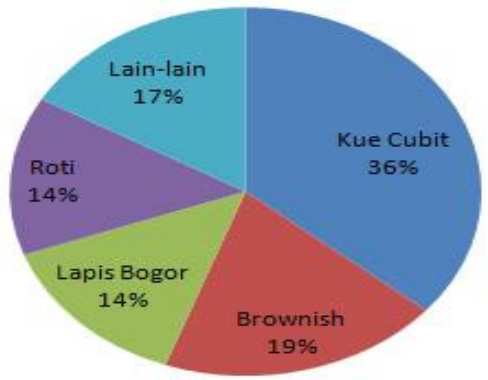

Gambar 1

Makanan/Kue Favorit Berbasis Teh Di Jawa Barat

Namun, berdasarkan hasil penelitian pada tahun 2014 dan 2016 (bekerjasama dengan Disbun Provinsi Jawa barat), dan tahun 2017 
(melalui dana HIU UNPAD) dapat diketahui bahwa kondisi agroindustri teh rakyat masih belum dapat berkembang dengan baik untuk dapat memenuhi tuntutan pasar, apalagi sampai menuju arah produk green tea powder yang berkualitas baik (sesuai permintaan pasar).

\begin{tabular}{|c|c|c|}
\hline $\begin{array}{l}\text { Kemampuan } \\
\text { Ketersediaan }\end{array}$ & $\begin{array}{l}\text { Mesin } \\
\text { Pucuk }\end{array}$ & $\begin{array}{l}\text { Olah } \\
\text { Teh }\end{array}$ \\
\hline
\end{tabular}

Perkembangan dan pertumbuhan agroindustri teh rakyat, sangat ditentukan oleh ketersediaan pucuk teh di kebun-kebun teh rakyat. Kurangnya ketersediaan pucuk teh sebagai bahan baku agroindustri menjadi salah satu penyebab semakin turunnya jumlah para pelaku agroindustri teh rakyat. Saat ini jumlah pelaku agroindustri teh rakyat di Jawa Barat semakin menurun, sebagai contoh, agroindustri teh rakyat di Kabupaten Cianjur pada tahun 2015 yang terdapat di Kecamatan: Sukanagara hanya tinggal enam unit dari 11 unit, Kecamatan Takokak hanya ada 11 unit dari 38 unit, dan Kecamatan Campaka tidak ada lagi agroindustri teh rakyat yang berdiri padahal beberapa tahun yang lalu terdapat tiga unit agroindustri teh rakyat (Dinas Perkebunan Kabupaten Cianjur, 2015). Kondisi tersebut, terjadi juga di daerah lain, seperti di Kecamatan Ciwidey Kabupaten Bandung, saat inipun hanya agroindustri milik Kelompok Tani Barokah yang masih tetap berjalan (dari empat agroindustri yang ada di Kecamatan Ciwidey Kabupaten Bandung). Sedangkan di Kabupaten Garut yaitu di kecamatan Cilawu, hanya KSU Putera Mekar yang dikenal sebagai Pabrik Teh Iroet, yang masih tetap bertahan.

Penyebab kurangnya ketersediaan pucuk teh sebagai bahan baku dalam agroindustri teh, adalah:1) banyaknya alih fungsi lahan, dimana tanaman teh diganti dengan tanaman tanaman kayu-kayuan, cabe dan sayuran lainnya (sebagai contoh: menyusutnya jumlah tanaman teh di Kabupaten Garut, yang seharusnya per ha terdapat 11.00012.000 pohon, diwilayah ini hanya ada hanya terdapat kurang lebih 6000 pohon/ha, sedangkan di Kabupaten Cianjur kurang dari 5000 pohon/ha), 2) kebun dibiarkan tidak terawat dengan baik, 3) pemetikan teh dilakukan dengan cara diarit, dan 4) harga jual pucuk yang rendah sebagai akibat budidaya yang kurang baik. Kondisi tersebut di atas, diperparah lagi dengan ketersediaan dan kemampuan mesin olah yang dimiliki pelaku agroindustri teh, serta permodalan yang dimiliki.

Salah satu contoh CV. Sugesti yang merupakan agroindustri yang merupakan perkembangan dari kelompok tani Agro Mandiri yang berlokasi di Kabupaten Cianjur Kecamatan Sukanagara ia hanya mampu memenuhi permintaan konsumen sebanyak $50 \%$ dari total permintaan konsumen (setiap harinya CV. Sugesti mendapatkan pasokan daun pucuk teh dari kebun pribadi adalah sekitar $200-500 \mathrm{~kg}$ dan pasokan daun pucuk teh dari petani mitra hanya sekitar $4.000-10.000 \mathrm{~kg}$ ). Kondisi ini diperparah lagi dengan kurangnya kapasitas terpasang dari mesin yang dimiliki.

Contoh lain dari kurang cepatnya perkembangan agroindustri teh rakyat, yaitu pada Kelompok Tani Barokah merupakan kelompok tani satu-satunya yang mengusahakan white teaDi Desa Lebak Muncang, Kecamatan Ciwidey, Kabupaten Bandung.Mereka menyatakan bahwa, kapasitas mesin olah yang dimiliki masih kurang yaitu hanya ada satu unit, yang hanya bisa menghasilkan $250 \mathrm{~kg} / \mathrm{hari}$ teh hijau, hal tersebut menyebabkan mereka kesulitan untuk memenuhi permintaa pasar. Menurut mereka, agar dapat memenuhi permintaan pasar maka mereka harus mempunyai dua unit mesin. Kondisi di atas, dialami pula oleh KSU Putera Mekar yang berlokasi di Kabupaten Garut Kecamatan Cilawu. Kecilnya kapasitas mesin produksi 
yang dimiliki KSU Putera Mekar, yaitu sebesar 5 Ton teh kering per hari, mempersulit Koperasi ini untuk memenuhi permintaan pasar sebesar 200 Ton per bulan sehingga kerap sulit memproduksi teh skala besar dalam waktu singkat. Menurut Ketua Koperasi, diperlukan mesin yang berkapasitas 2x lipat besarnya untuk dapat memenuhi besarnya permintaan tersebut.

Melihat contoh kondisi ketiga agroindustri teh rakyat tersebut di atas, maka dilihat dari kemampuan dan ketersediaan mesin dan pucuk teh, maka akan dapat menjadi penghambat berkembangnya agroindustri teh rakyat di Jawa Barat; dengan kata lain, bila dipandang dari aspek tknis/operasi baik ditingkat kebun maupun pabrik maka usaha agroindustri teh rakyat akan sulit untuk dapat terus berkelanjutan.

\section{Kemampuan Finansial dan Tenaga Kerja yang Dimiliki Agroindustri Teh Rakyat}

Pada umumnya, agroindustri teh rakyat tidak memiliki pencatatan dan pembukuan yang baik, sehingga mereka mengalami kesulitan pada saat akan merencanakan pengembangan usahanya. Hal inipun terjadi untuk KSU Putera Mekar dan Kelompok Tani Barokah, kondisi ini terjadi karena sumberdaya manusia yang dumiliki oleh kedua agroindustri teh rakyat tersebut memiliki pendidikkan setara dengan SMA. Kondisi tersebut berbeda dengan CV. Sugesti yang diketuai oleh seorang pimpinan lulusan perguruan tinggi. Oleh karena itu, untuk menggambarkan analisis financial dari salah satu agroindustri the rakyat dapat dimabil contoh dari CV. Sugesti. Berdasarkan perhitungan $\mathrm{RC}$ ratio $\mathrm{CV}$. Sugesti daperoleh nilai 1,039 dan nilai tersebut lebih besar dari pada 1. Artinya, CV. Sugesti masih cukup layak untuk terus menjalankan usahanya. Selain itu bila dilihat dari keuntungan yang diperoleh setiap bulannya (walaupun sangat fluktuatif) masih memberikan keuntungan, walaupun pada bulan November pernah mengalami kerugian.

Tabel 1

Data Biaya dan Pendapatan CV. Sugesti (x 1000)

\begin{tabular}{|lrrrrrr|}
\hline Bulan & $\begin{array}{l}\text { Jumlah } \\
\text { Produksi } \\
(\mathrm{Kg})\end{array}$ & $\begin{array}{l}\text { Biaya Tetap } \\
(\mathrm{Rp})\end{array}$ & $\begin{array}{l}\text { Biaya } \\
\text { Variabel } \\
(\mathrm{Rp})\end{array}$ & $\begin{array}{l}\text { Biaya } \\
\text { Total } \\
(\mathrm{Rp})\end{array}$ & $\begin{array}{l}\text { Pendapatan } \\
\text { Total (Rp) }\end{array}$ & $\begin{array}{l}\text { Keuntungan } \\
(\mathrm{Rp})\end{array}$ \\
\hline Januari & 57.995 & 28.000 & 733.828 & 761.828 & 787.920 & 26.091 \\
Februari & 54.201 & 28.000 & 662.614 & 690.614 & 725.859 & 35.245 \\
Maret & 55.361 & 28.000 & 675.204 & 703.204 & 727.886 & 24.682 \\
April & 54.035 & 28.000 & 672.887 & 700.887 & 719.098 & 18.210 \\
Mei & 67.635 & 28.000 & 820.686 & 848.686 & 920.986 & 72.299 \\
Juni & 59.797 & 28.000 & 730.695 & 758.695 & 820.534 & 61.839 \\
Juli & 37.882 & 28.000 & 476.913 & 504.913 & 511.104 & 6.191 \\
Agustus & 37.682 & 28.000 & 482.404 & 510.404 & 516.055 & 5.651 \\
September & 46.684 & 28.000 & 558.593 & 586.594 & 652.082 & 65.448 \\
Oktober & 50.809 & 28.000 & 661.169 & 689.169 & 702.688 & 13.518 \\
November & 39.205 & 28.000 & 543.482 & 571.483 & 532.129 & -39.353 \\
Desember & 49.360 & 28.000 & 646.502 & 674.502 & 693.261 & 18.759 \\
\hline TOTAL & $\mathbf{6 1 0 . 6 1 0}$ & $\mathbf{3 3 6 . 0 0 0 . 0 0 0}$ & $\mathbf{7 . 6 6 4 . 9 8 1}$ & $\mathbf{8 . 0 0 0 . 9 8 1}$ & $\mathbf{8 . 3 0 9 . 6 0 4}$ & $\mathbf{3 0 8 . 5 8 3}$ \\
\hline
\end{tabular}

Sumber: CV. Sugesti, Tahun 2017

Ketidakstabilan usaha agroindustri teh rakyat CV. Sugesti dapat dilihat dari berfluktuasinya hasil biaya total dan pendapatan total yang didapatkan pihak $\mathrm{CV}$. Sugesti setiap bulannya, yang dapat dilihat pada bulan November biaya total lebih besar dari pada pendapatan total. Ini disebabkan hasil penjualan teh hijau olahan CV. Sugesti yang menurun, sebagai akibat menurunnya persedian bahan baku (pucuk teh) sedangkan 
biaya proses produksi yang harus dikeluarkan tetap jumlahnya. Sedangkan pada bulan Mei dan Juni terjadi peningkatan pendapatan total, karena pada bulan Mei dan Juni persediaan bahan baku (daun pucuk teh segar) cukup banyak sehingga dapat menghasilkan jumlah produksi teh kering yang banyak pula.

Sebagian besar petani teh di Kabupaten Garut, Bandung dan Cianjur memiliki tingkat pendidikan yang rendah, tetapi walaupun demikian, hamper setengahnya petani teh di ketiga wilayah tersebut pernah mengikuti pelatihan yang diberikan oleh instansi pemerintah terkait seperti misalnya: Dishutbun, Disperindag, dan lainlain.Pelatihan yang pernah diikuti Petani dalam usaha pemerintah untuk meningkatkan pengetahuan dan keterampilan petani teh, misalnya: budidaya teh (pembibitan, pemupukan, pemetikan, penyiangan dan pengendalian gulma), dinamika kelompok, SLPHT (Sekolah Lapangan Pelatihan Hama Terpadu), SKE (Sistem Kebersamaan Ekonomi), pelatihan dinamika kelompok dan kelembagaan. Tidak hanya pelatihan yang diberikan oleh pemerintah, pemberian bantuan bibit teh unggul dan pupuk, juga mengadakan program intensifikasi, program PIR dan ADB, serta pembuatan pupuk organik (bokasi). Apabila dilihat dari materi pelatihan yang diterima petani maka, terlihat bahwa materi lebih besar muatannya untuk ke budidaya, sedangkan untuk kearah agroindustri masih minim sekali.

Untuk mendukung pengembangan agroindustri teh rakyat, harus didukung oleh SDM yang tersedia, yang memiliki kemampuan untuk mengelola kebunnya dengan baik agar memberikan pucuk teh dalam jumlah yang besar dan berkualitas untuk menjadi sumber bahan baku bagi agroindustri the rakyat. Sayangnya, kebun teh yang dikelola petani di Kabupaten Garut, Bandung dan Cianjur belum mampu untuk menyediakan pucuk teh untuk bahan baku agroindustri the rakyat, baik dari sisi produktivitas, kualitas maupun kontinyuitas. Padahal, syarat utama untuk mengembangkan agroindustri teh harus berjalan dari hulu (kemampuan menyediakan bahan baku, yaitu berupa pucuk teh) sampai ke hilir. Selain itu, pelatihan dan pembinaan dari sisi agroindustri, belum disentuh dengan baik oleh pemerintah daerah (walaupun ada bantuan mesin olah), yaitu dalam sisi manajemen industri dan manajamen bisnis. Oleh karena itu, bila dilihat dari sisi SDM belum cukup layak untuk bergerak mengembangkan agroindustri teh rakyat.

Apabila dilihat dari daya serap usaha dibidang agroindustri teh rakyat, maka sebenarnya memiliki potensi yang cukup baik untuk mengurangi pengangguran di desa. Sebagai contoh: pabrik teh KSU Putera Mekar di Garut dapat menyerap sekitar 15 tenaga kerja yang kerja di pabrik, dan 150 orang pekerja di tingkat kebun (yang memasok pucuk teh ke pabrik). Selanjutnya, pabrik milik Kelompok Tani Barokah di Bandung telah menyerap sekitar 8 orang tenaga kerja dan 26 orang pekerja di kebun yang memasok pucuk ke pabrik. Kecilnya daya serap pekerja di pabrik disebabkan karena ketersediaan mesin olah yang masih minim. Walaupun memiliki mesin yang terbatas, tetapi kedua agroindustri tersebut di atas, dapat menampung pucuk teh dari masyarakat sekitarnya dan di luar wilayah (ini terjadi bila kondisi pucuk teh dikebun yang mereka kelola mengalami defisit). Selanjutnya, pabrik teh CV. Sugesti yang dapat menyerap tenaga kerja cukup banyak. Jumlah pekerja di agroindustri rakyat $\mathrm{CV}$. Sugesti sekitar 350 orang yang terdiri dari 38 pekerja di kebun, 4 pekerja administrasi, 53 pekerja pengolahan dan sortasi, 10 supir, 4 sales, dan 185 pekerja pengemas produk yang tersebar di tiga gudang yaitu gudang pengemasan I di Kampung Leuwikadu, Desa Gunungsari, 
Kecamatan Sukanagara, gudang pengemasan II di Kampung Leuwimanggu, Desa Sukakarya, Kecamatan Sukanagara dan gudang pengemasan III di Kampung Cangkring Jelekong, Baleendah, Kabupaten Bandung. Mayoritas pekerja di CV. Sugesti merupakan warga lokal yang berada di sekitar wilayah pabrik dan gudang pengemasan. Lowongan pekerjaan sengaja diberikan oleh CV. Sugesti untuk masyarakat sekitar dalam rangka membantu memberdayakan perekonomian warga sekitar sebagai bentuk Corporate Social Responsbility (CSR) perusahaan.

\section{Peluang Pengembangan Agroindustri Teh Rakyat}

Produksi teh di Jawa Barat 95 persen masih dalam berbentuk teh curah, hanya 5 persen dalam bentuk produk retail/hilir, hal ini bias merupakan peluang pengembangan agroindustri teh rakyat, yang pada akhirnya diharapkan dapat mendongkrak perkebunan teh rakyat di Jawa Barat. Jika dibandingkan dengan negara produsen teh lainnya, seperti India dan Kenya; Indonesia masih dinilai jauh tertinggal dalam pengembangan industri hilir tehnya. Nilai ekspor teh dalam bentuk produk lanjutan di India pada tahun 2014 mencapai 21 persen dari total nilai ekspor teh dunia (International Tea Committee, 2015).

Sampai saat ini Indonesia masih mengandalkan teh curah dalam ekspor tehnya. Padahal, permintaan akan produk teh bernilai tambah tinggi seperti aneka makanan dan minuman berbasis teh, dan industry suplemen baik di pasar dalam negeri maupun ekspor demikian tinggi. Pertumbuhan pasar dalam negeri untuk produk-produk berbasis tea powder masih tumbuh sekitar 27 persen per tahun, untuk produk-produk suplemen per tahun sekitar 28 persen (Suhartini,2009). Kondisi tersebut, memperlihatkan gambaran perlunya pengembangan produk hilir teh bernilai tambah tinggi yang mampu meningkatkan nilai ekonomis teh Indonesia, khususnya teh yang berasal dari perkebunan teh rakyat. Itu dapat dilakukan melalui pengembangan agroindustri teh rakyat. Peluang pengembangan agroindustri teh rakyat masih sangat memungkinkan, hal ini dapat dilihat dari beberapa hal, yaitu:

1) Adanya program GPATN (Gerakan Penyelamatan Agribisnis Teh Nasional) dari pemerintah yang dimulai pada April 2014.

2) Tetap tumbuhnya permintaan teh Indonesia sebesar 3 persen per tahun dalam satu dekade ${ }^{1)}$

3) Banyaknya permintaan pucuk teh sebagai bahan baku olahan teh yang diperlukan pabrikan dalam negeri, hal ini terlihat dari hasil penelitian yang menunjukan selalu terjualnya pucuk teh yang dihasilkan petani walaupun kualitas pucuk tidak memenuhi persyaratan yang baik (karena pada umumnya pemetikan dilakukan petani dengan cara di arit).

4) Perkebunan teh rakyat dapat menyerap banyak tenaga kerja (dapat digunakan untuk mengurangi pengangguran) mulai dari hulu sampai ke hilir.

5) Pengembangan industri hilir teh berupa" Instant Tea " (makanan, minuman, farmasi, kosmetik).

6) Mengisi ceruk pasar untuk teh kwalitas " premium ".

7) Pengembangan diversifikasi produk dan pasar untuk produk suplement kesehatan berupa "effervescent tea" yang tinggi kandungan anti oksidan.

8) Dalam Agribisnis Teh 2016-2045 dari Direktorat Tanaman Pangan dan Penyegar, Direktorat Jendral Perkebunan-Kementerian Pertanian (2015), dinyatakan bahwa:

a. Agroindustri teh masih tumbuh dengan laju penyerapan bahan baku sebesar 29.4 persen per tahun, dan laju 
nilai produksi sebesar 10.4 persen per tahun selama lima tahun terakhir,

b. Pasar dalam negeri masih berpotensi untuk dikembangkan dari konsumsi 330 gram/kapita/tahun ditingkatkan menjadi 600 gram/kapita/tahun dalam lima tahun mendatang.

c. Pasar ekspor masih tumbuh untuk mengisi pasar teh Rusia, China, dan India yang merupakan negara-negara konsumen teh dengan pertumbuhan ekonomi yang tinggi.

Peluang pengembangan agroindustri teh sangat besar, hal ini dapat dilihat dari gambaran rasio nilai tambah industri teh siap minum yang mencapai 0,859 artinya, setiap seribu rupiah dari nilai produk teh siap minum yang diproduksi dapat diperoleh nilai tambah sebesar Rp.859,00. Dilain pihak, rasio nilai tambah dari industri pengemasan teh hitam dan teh hijau masing-masing mencapai 0,443 dan 0,448 ; artinya setiap seribu rupiah nilai teh hitam dan teh hijau kemasan yang diproduksi, masing-masing bernilai tambah sebesar Rp. 443,00 dan Rp. 448,00 (Suprihatini dan J. Santoso, 2007).elanjutnya, Suprihatini dan J. Santoso (2007) juga menyatakan bahwa, dalam konteks pengembangan industri teh, baik industri teh curah dan teh olahan mempunyai potensi untuk dikembangkan karena nilai keterkaitan ke depan dan ke belakang secara langsung maupun tidak langsung lebih besar dari satu, yakni 1,54 kali lipat. Artinya, peningkatan permintaan di industri teh curah dan teh olahan sebesar satu satuan akan menungkatkan output di semua industri teh.

1) Lahan Perkebunan Terbatas, Ekspor Teh Indonesia terus menurun. https://katadata.co.id/berita/2016/11/21. Diakses tanggal 4 Januari 2018.

\section{Kendala dalam Pengembangan Agroindustri Teh Rakyat}

Dari hasil pene;itian, dapat diketahui adanya beberapa kendala yang dihadapi dalam usaha mengembangkan agroindustri teh rakyat, baik yang berasal dari internal maupun eskternal petani dan kelompok tani sebagai pelaku agroindustri itu sendiri, yaitu: 1) dinamika kelompok tani belum berjalan dengan baik, 2) kesadaran petani untuk berkelompok masih kurang, 3) ketergantungan petani terhadap bantuan pemerintah masih cukup tinggi, 4) masih kurangnya tenaga penyuluh di bidang perkebunan, 5) pembinaan yang telah dilakukan pemerintah sifatnya belum kontinyu dan bersifat kurang sistematis, 6) materi pembinaan yang diberikan kepada petani dilakukan kurang terintegrasi dan terkoordinasi mulai dari hulu sampai ke hilir, dan 7) belum adanya keterbukaan informasi dalam intern kelompok. Selain kendala tersebut di atas, masih terdapat kendala lainnya yang terkait secara langsung dalam kegiatan agroindustri itu sendiri, yaitu masih kurang dalam: 1) ketersediaan pucuk teh sebagai bahan baku, 2) pengetahuan untuk meningkatkan nilai tambah pucuk teh, 3) kemampuan penyediaan modal dan mesin olah pucuk teh, dan 4) dukungan pemerintah dalam mempromosikan teh olahan rakyat (misalnya: dalam rapat atau kegiatan yang berlangsung di pemerintahan belum memanfaatkan produk olahan teh dari petani). Kondisi ini akan berdampak langsung maupun tidak langsung terhadap keberlanjutan agroindustri teh rakyat.

\section{Usaha Pengembangan Agroindustri Teh Rakyat}

Untuk mengembangkan aroindustri teh rakyat harus dimulai dari hulu sampai ke hilir, dan itu dapat digambarkan melalui pendekatan system thinking, yaitu pendekatan untuk memahami perubahan dan kompleksitas yang dipacu oleh peubah yang dinamis dan perjalanan waktu. Salah satu alat yang dapat digunakan dalam pendekatan system thinking adalah causal loop modelling. Hasil dari pendekatan system 
thinking melalui causal loop modelling dalam menelitian ini dapat dilihat dalam causal loop diagram pada Gambar sebagai berikut:

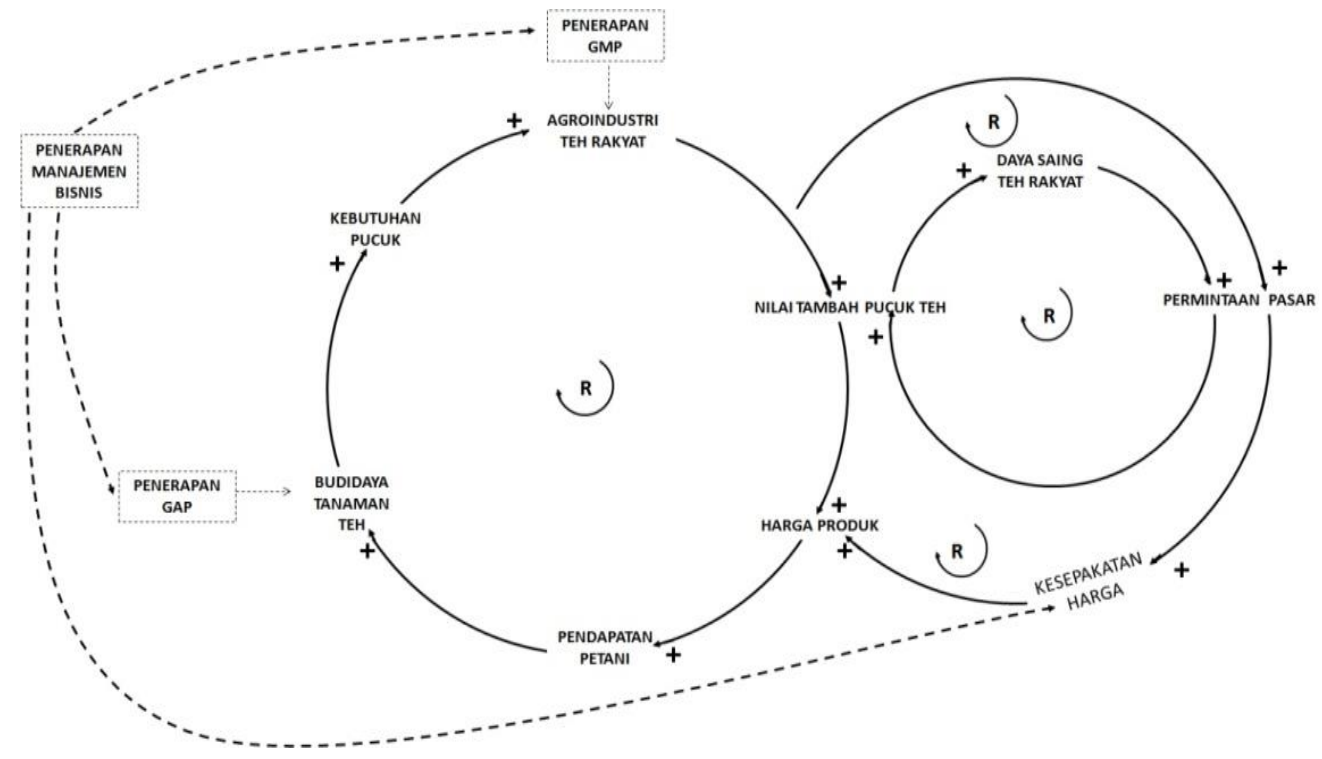

Gambar 2.

Pengembangan Agroindustri Teh Rakyat

Pengembangan agroindustri teh rakyat dapat dilakukan melalui fasilitasi pemerintah dalam bentuk bantuan mesin pengolahan dalam skala kecil yang dapat dilakukan melalui kumpulan kelompok tani (Gapoktan). Tetapi sebelum memfasilitasi Gapoktan untuk menjadi suatu usaha agroindustri skala kecil, maka yang harus dilakukan oleh pemerintah daerah adalah, dengan melakukan pembinaan dalam hal penerapan GMP di tingkat manufacture milik Gapoktan, dan pembinaan dalam penerapan GAP untuk tanaman teh di tingkat kelompok tani. Pembinaan GAP pada tanaman teh milik kelompok tani, bertujuan untuk meningkatkan mutu pucuk teh yang dihasilkan, sehingga dapat menunjang kontinyuitas kebutuhan bahan baku bagi usaha agroindustri teh rakyat baik dari segi kuantitas yang tinggi maupun kualitas, yang pada akhirnya agroindustri teh rakyat dapat berdaya saing tinggi dipasaran (memiliki nilai tambah yang tinggi).
Meningkatnya daya saing teh rakyat melalui pengembangan agroindustri teh rakyat, akan meningkatkan permintaan pasar, dan ini pada akhirnya pelaku agroindustri teh rakyat memiliki bargaining position yang tinggi. Hal ini memerlukan kemampuan dalam menentukan kesepakatan harga teh olahannya dengan para mitranya. Selanjutnya, agar pengusaha (petani) teh rakyat memiliki kemampuan dan mandiri dalam menghadapi pasar bebas atau internasional, maka pelatihan yang menyangkut kegiatan di hulu (penerapan GAP) dan hilir (penerapan GMP), pemasaran, serta manajemen bisnis menjadi suatu keharusan.

\section{Kesimpulan}

Melalui agroindustri, maka petani dan kelompok tani tidak lagi menjual produk hulu (pucuk teh), tetapi menjual produk antara (teh hijau) atau hilir (produk turunan dari teh hijau) yang memiliki nilai tambah lebih tinggi. Selanjutnya, dengan nilai 
tambah yang tinggi, akan berdampak kepada peningkatan pendapatan petani perkebunan teh rakyat, yang pada akhirnya dapat meningkatkan kesejahteraan mereka.

Namun, masih ada beberapa kendala yang dihadapi agroindustri teh rakyat, yaitu masih kurang dalam: 1) ketersediaan pucuk teh sebagai bahan baku, 2) pengetahuan untuk meningkatkan nilai tambah pucuk teh, 3) kemampuan penyediaan modal dan mesin olah pucuk teh, dan 4) dukungan pemerintah dalam mempromosikan teh olahan rakyat (misalnya: dalam rapat atau kegiatan yang berlangsung di pemerintahan belum memanfaatkan produk olahan teh dari petani). Kondisi ini berdampak terhadap keberlanjutan agroindustri teh rakyat.

Pengembangan agroindustri teh rakyatmasih memiliki peluang yang baik, hal ini terlihat dari tingginya permintaan teh olahan di pasar lokal maupun internasional. Oleh karena itu, usahapengembangan agroindustri teh rakyat dapat dilakukan melalui strategi pemberdayaan kemandirian sumberdaya petani berbasispada: peningkatan kemampuan dan keterampilan teknologi hulu dan hilir, dukungan Permodalan dan Pemasaran, serta manajamen bisnis. Selain itu, perlu adanya regulasi yang mendukung pengembangan teh rakyat mulai dari hulu sampai ke hilir (agroindustri teh rakyat).

\section{Daftar Pustaka}

Bisnis Indonesia. 23 September 2013. Jabar Siap Revitalisasi Kebun Teh. (http://epaper.bisnis.com/)

Departemen Pertanian 2008. Pedoman Budidaya Tanaman Biofarmaka yang baik (Good Agriculture Practices). Dirjen Hortikultura.

Dinas Perkebunan Jawa Barat. 2006. Inventarisasi Pendapatan/Daya Beli Petani Pada Perkebunan Rakyat Di Provinsi Jawa Barat.
Dinas Perkebunan Jawa Barat. 2014. Kajian Pengembangan Kawasan Agribisnis Teh Rakyat Di Provinsi Jawa Barat.

Direktorat Jenderal Perkebunan, 2015.Statistik Perkebunan Indonesia 2014-2016 Teh.

Direktorat Tanaman Tahunan dan Penyegar, Direktorat Jenderal PerkebunanKementerian Pertanian, 2015. Pengembangan Agribisnis Teh 20162045. Jakarta.

Fakultas Pertanian UNPAD dan Dinas Perkebunan Provinsi Jawa Barat. 2006. Inventarisasi

Pendapatan/Daya Beli Petani Pada Perkebunan Rakyat Di Provinsi Jawa Barat.

Forum Sertifikasi Teh Indonesia. 2010. Good Agricultural Practices. Newsletter Sustainable Tea. Edisi September-Oktober 2010.

International Tea Committee. 2015. Annual Bulletin of Statistics 2015. International Tea Committee, London.

Lexi J. Moleong, M. A. 2001. Metodologi Penelitian Kualitatif. Bandung: Rosda Karya

Lucyana Trimo, Rohayati Suprihatini, Kralawi Sita, Shabri dan Hilman Maulana.2015. Pengujian Produk dan Pasar Tepung Teh Sebagai Bahan Baku Industri Minuman, Makanan dan Biofarmaka Di Jawa Barat. BP3IPTEK dan UNPAD.

Rusidi. 1996. Metode Ilmiah. Fakultas Pertanian Universitas Padjadjaran. Jatinangor 
Agricore Volume 4 Nomor 1, Juli 2019 Jurnal Agribisnis dan Sosial Ekonomi Pertanian UNPAD p-ISSN No. 2528-4576 / e-ISSN No. 2615-7411

Suharsimi Arikunto, Prosedur Penelitian Suatu Pendekatan Praktek:
EdisiRevisi V (Jakarrta Rineka Cipta, 2002), 